\title{
Zinc - responsive dermatosis in a fila brasileiro
}

\author{
Dermatose responsiva ao zinco em fila brasileiro
}

\author{
Adriane Pimenta da Costa-Val ${ }^{\text {I }}$ Sandra Regina Marinho Gonçalves ${ }^{\text {II }}$ \\ Karita Dannille Assis Borges ${ }^{\text {II }}$ Fernanada dos Santos Alves ${ }^{\text {III }}$ \\ Lissandro Gonçalves Conceição ${ }^{\mathrm{IV}}$
}

\begin{abstract}
Nowadays zinc - responsive dermatosis is reported in many species. In dogs, the zinc - responsive dermatosis exists in two different forms named as Syndrome I and II. The former occurs mainly in Nordic breed dogs, as these animals may present a genetic defect that interferes with intestinal zinc absorption. Syndrome II occurs in rapidly growing puppies fed zinc-deficient diets or diets containing an excess of calcium or phytate, and has been described in many breeds, but no reports on Fila Brasileiro were found in literature. A case of zinc responsive dermatosis in a Fila Brasileiro puppy is described for the first time.
\end{abstract}

-NOTE-
Key words: dog, calcium, phytate and skin.

\section{RESUMO}

A dermatose responsiva ao zinco tem sido relatada em muitas espécies. Nos cães, tal dermatose existe em duas formas diferentes, denominadas Síndrome I e II. A primeira ocorre principalmente em animais de raças nórdicas, que podem apresentar alteração genética que interfere com a absorção intestinal de zinco. A Síndrome II ocorre em cães de crescimento rápido, alimentados com dietas deficientes em zinco ou que contenham excesso de cálcio ou fitato, o que contribui para a baixa absorção de zinco. Sua ocorrência foi descrita em cães de diversas raças, mas não há relatos da ocorrência da Síndrome em Fila Brasileiro. Descreve-se pela primeira vez um caso de dermatose responsiva ao zinco em um filhote de Fila Brasileiro.

Palavras-chave: cão, cálcio, fitato e pele.
Among the trace elements found in living organisms, zinc is one of the most important and is typically present high concentration, secondly only to iron. This element is essential for many functions in body metabolism, mainly in the regulation of keratogenesis and wound healing, as well as in the maintenance of normal acuity of taste and smell (CASE et al., 1998; COLOMBINI, 1999). Approximately 2\% of the total body store of zinc is found in the skin, with the epidermis containing six times more of the element than the dermis. Zinc concentrations tend to be higher in tissues with high epithelial proliferation rates, and normally parakeratotic sites such as the nose, as well as keratinised pressure areas, as the footpads, contains zinc largest concentrations (COLOMBINI, 1999).

All animals require a continuous supply of zinc in their diet since readily available body stores are limited. The dietary requirements of the element vary according to the species and function of the animal as well as its age and health status. Thus, young growing animals and breeding females require higher levels of zinc than healthy, non-reproducing adults (COLOMBINI \& DUNSTAN, 1997). The nature of the diet is also important since zinc is more readily absorbed from animal products than from those originating from plants (CASE et al., 1998). Moreover, zinc absorption

IEscola de Veterinária, Universidade Federal de Minas Gerais (UFMG), Avenida Presidente Antônio Carlos, 6627, 31270-901, Belo Horizonte, MG, Brasil. e-mail: adriane@ufmg.br. Autor para correspondência.

IIPrograma de Residência em Clínica Médica de Pequenos Animais, UFMG, Belo Horizonte, MG, Brasil.

IIICurso de Medicina Veterinária, Escola de Veterinária, UFMG, Belo Horizonte, MG, Brasil.

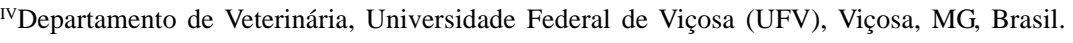


and utilisation may be influenced by the presence of other dietary ingredients, such as phytate, which is present in many types of vegetable protein (KWOCHKA, 1993; CASE et al., 1998; SCOTT et al., 2001; WHITE, 2001). Excess calcium may also inhibit the intestinal absorption of zinc, possibly through competition for absorption sites or by acting as intestinal ligands (CASE et al.,1998; WHITE, 2001).

The National Research Council (NRC) established guidelines relating to the dietary requirements of zinc for a number of animal species. Growing puppies and adults under stress associated with pregnancy, lactation, or illness may require two to three times the NRC recommended level.(NATIONAL RESEARCHCOUNCIL, 1985).

In dogs, zinc-responsive dermatosis is an uncommon disease that is classified into two distinct syndromes. Although other breeds can also be affected, Syndrome I occurs mainly in Siberian Huskies and Alaskan Malamutes, and derives from a genetic defect in the animal resulting in decreased intestinal absorption of zinc (CASE et al., 1998; KWOCHKA, 1993; SCOTT et al., 2001; WHITE, 2001). Dogs with syndrome I may require zinc supplementation for life (CASE et al., 1998).

Syndrome II typically appears in rapidly growing puppies of various breeds that have been fed on zinc-deficient diets or diets containing an excess of phytate or minerals, particularly calcium (CASE et al., 1998; WHITE, 2001). In any one litter, the severity of the clinical signs can be highly variable, with some puppies appearing normal whilst others present depression, anorexia, stunted growth, pyrexia, and lymphadenopathy (COLOMBINI, 1999). The dermatological lesions often involve the head and pressure points. Fissuring in areas of hyperkeratosis, such as footpads and the nasal planum, may also be found (CASE et al., 1998; KWOCHKA, 1993; SCOTT et al., 2001; WHITE, 2000).

The diagnosis of zinc-responsive dermatosis must be based on a thorough history, physical examination, fungal culture of skin scrapes and histopathological examination of skin biopsies (COLOMBINI, 1999; SCOTT et al., 2001). The treatment for dogs presenting zinc-responsive dermatosis syndrome II includes appropriate adjustment of the diet and the suspension of calcium supplementation. This therapy is generally sufficient for the resolution of the lesions within 2 to 6 weeks.

A Fila Brasileiro bitch of age 5 months was brought into the Dermatological Service at the Veterinary Hospital of the Universidade Federal de Minas Gerais, Belo Horizonte-MG, Brazil, with a one- month history of crusty lesions on the lips, nose, chin, vulva and metatarsus. Pruritus was not observed. The animal had been fed on generic adult dog food and had received ferrous calcium citrate $555 \mathrm{mg}$, BID supplementation since the age of 2 months. Clinical examination revealed intense erythema on both upper and lower lips, crust lesions on the chin (Figure 1a) and around the nose. Many small areas with hypotrichosis, and crusts were observed on the cranial face of the hind limbs encircling the footpads (Figure $1 \mathrm{~b}$ ), and on the cranial and lateral hind limbs (Figure 1c). Erythema and crusts in the interdigital areas observed (Figure 1d). No other clinical parameters were altered.

No Demodex mites or dermatophytes were found microscopically in skin scrapings. No dermatophytes were cultured. Two skin samples from crusted areas were taken for histopathological examination: one from the chin (Figure 1a) and one from lateral aspect of a footpad. The skin biopsies revealed discrete acanthotic epidermis with focal areas showing mononuclear cell exocytosis. There was extensive parakeratotic hyperkeratosis, alternated with serocelluar crusts and orthokeratotic hyperkeratosis. The hair follicles exhibited dilatation and infundibular parakeratotic hyperkeratosis conferring a pseudopapillomatous aspect to the epidermis. The superficial dermis showed segmentar zones of oedema, cell proliferation, ectasia, vascular congestion and mixed-type angiocentric cellular infiltration, mainly lymphocytes, macrophages and plasma cells (Figure 2). No alterations were found in the pilosebaceous annexes. No mites were found in the material.

The histopathological findings were consistent with of zinc-responsive dermatosis. As suggested in the literature (COLOMBINI \& DUNSTAN, 1997; COLOMBINI, 1999) the diet of the animal was upgraded and the calcium supplementation was suspended, but no zinc supplementation was prescribed. In 5 weeks, in a recheck appointment, no skin lesions were seen.

Zinc plays important roles in many body structures and functions, and its absorption may be decreased by calcium supplementation and in dogs feed with poor quality food, that may also contains high phytate concentrations (WATSON, 1998; COLOMBINI, 1999). These facts, taken together are believed to be the causes of Syndrome II in a Fila Brasileiro puppy described in this paper.

The lesions observed in the puppy are in accordance with those described in literature for dogs 


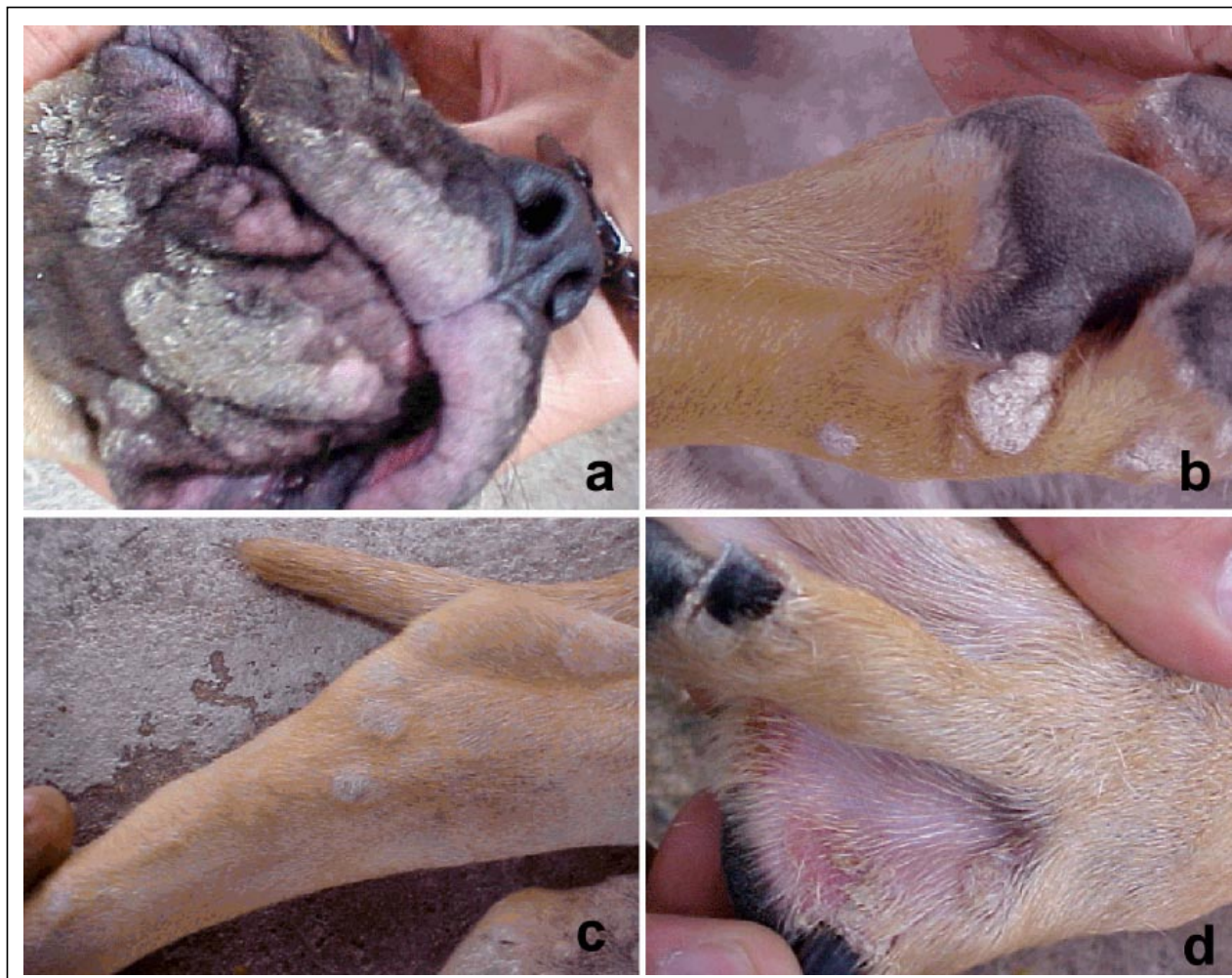

Figure 1 - (a) Erythema can be seen in the lips, as well as multifocal crusty areas on the chin. (b) Footpad of the puppy showing a large and some small crusty lesions. (c) Lateral aspect of the hind limb of the case showing many small areas with hypotrichosis and crusts. (d) linterdigital areas of the puppy showing erythema and crusts.

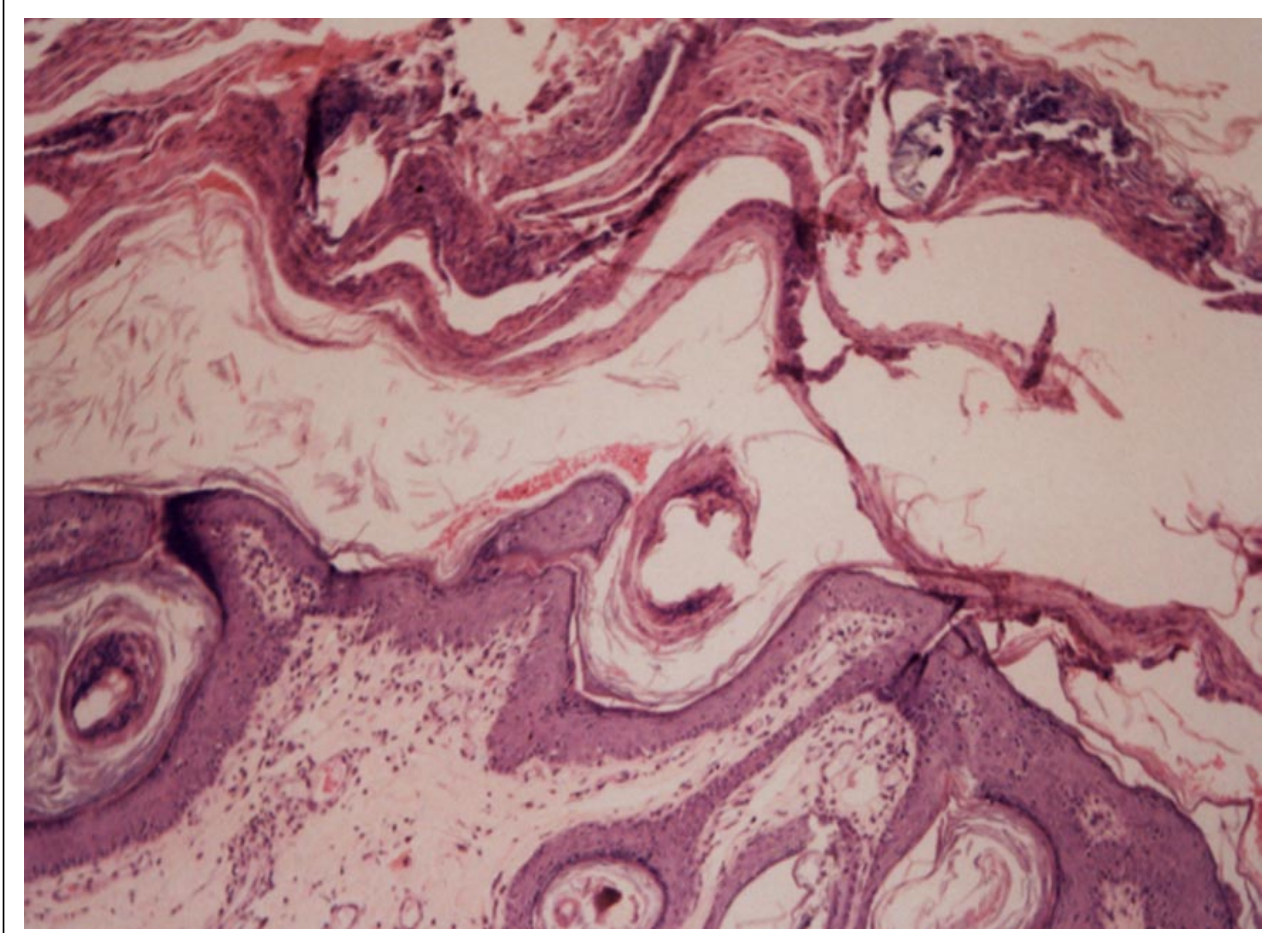

Figure 2 - Photomicrogaphy showing crusts, epidermis with extensive parakeratosis, infundibular parakeratosis conferring a pseudo-papillomatous aspect to the epidermis and small zones of oedema in the superficial dermis (HE X 100). 
presented with zinc-responsive dermatosis: the head and pressure points of the limbs were mostly involved (COLOMBINI, 1999). Fissuring areas in a footpad were also found, according to cases described before (KWOCHKA, 1993; SCOTT et al., 2001; WHITE, 2001). The puppy was otherwise health, as described elsewhere (COLOMBINI, 1999).

A thorough history with diet investigation, mineral supplementation and a careful clinical examination were essential for leading to the diagnosis. Histological characteristics as described in the literature, were of fundamental importance in leading to the definitive diagnosis(COLOMBINI, 1999; SCOTT et al., 2001)

In this case report only the adjustment of the diet and the suspension of the calcium supplementation were enough to the healing of the lesion within few weeks. No zinc supplementation was needed, as described elsewhere (COLOMBINI \& DUNSTAN, 1997)

In conclusion, zinc-responsive dermatosis was firstly diagnosed in a Fila Brasileiro puppy. This case suggests that every animal of fast growing breeds can develop the Syndrome II type of zinc responsive dermatosis and also highlight the need of feeding these animals with high quality food, as well as veterinary actions towards discouraging owners to use calcium supplements, without veterinary prescription.

\section{ACKNOWLEDGMENT}

Research supported by Fundação de Amparo à Pesquisa do Estado de Minas Gerais (FAPEMIG).

\section{REFERENCES}

CASE, P. et al. Nutrição canina e felina: manual para profissionais. Madrid: Harcout Brace de España, 1998. 424p.

COLOMBINI S. Canine zinc-responsive dermatosis. Veterinary Clinics of North America: Small Animal Practice, v.29, p.1373-1383, 1999.

COLOMBINI, S; DUNSTAN, R.W. Zinc-responsive dermatosis in northern-breed dogs: 17 cases (1990-1996). Journal of American Veterinary Hospital Association, v.211, n.4, p.451-453, 1997.

KWOCHKA, K.W. Primary keratinization disorders of dogs. In: GRIFFIN, C.E. et al. Current veterinary dermatology: the science and art of therapy. St. Louis: Mosby Year Book, 1993. Cap.5, p.176-190.

NATIONAL RESEARCH COUNCIL. Nutritional requirements of dogs. Washington DC: National Academic, 1985. 348p.

SCOTT, D.W. et al. Nutritional skin diseases. In: Scott, D.W.: Muller \& Kirk's Small animal dermatology. 6.ed. Philadelphia: Saunders, 2001. p.1112-1124.

WATSON, T.D.G. Diet and skin diseases in dogs and cats. Journal of Nutrition, v.128, supl., p.2783-2789, 1998.

WHITE, S.D. et al. Zinc-responsive dermatosis in dogs: 41 cases and literature review. Veterinary Dermatology, v.12, p.101-109, 2001. 